\title{
Collaborative Economy in Peru: Past, Present and Future
}

\section{Víctor Hugo Fernández-Bedoya ${ }^{1}$, Johanna de Jesús Stephanie Gago-Chávez ${ }^{2}$, Mónica Elisa Meneses-la-Riva ${ }^{1}$, Josefina Amanda Suyo-Vega ${ }^{1}$}

\author{
${ }^{1}$ Universidad César Vallejo \\ 6232 Alfredo Mendiola, Los Olivos, Lima, Perú \\ ${ }^{2}$ Universidad ESAN \\ 1652 Alonso de Molina, Monterrico, Surco, Lima , Perú
}

DOI: $10.22178 /$ pos.58-5

JEL Classification: D16

Received 23.04.2020

Accepted 28.05.2020

Published online 31.05.2020

Corresponding Author:

Víctor Hugo Fernández-Bedoya

victorhugofernandezbedoya@gmail.com

(C) 2020 The Authors. This article

is licensed under a Creative Commons

Attribution 4.0 License @) (1)

\begin{abstract}
The collaborative economy is a phenomenon that has accompanied us over the years; society has evolved thanks to the collaboration between the individuals that make it up. Through a deep qualitative analysis of grounded theory, the researchers analyzed twentyfour models of collaborative economy detailed in the literature, to know which ones are already experienced in Peru and which ones are not. The results showed that formal activities related to collaborative economy are already in operation, such as car rental, bicycle usage, film usage, varied objects rentals, online commerce, exchanges, room rental, crowdfunding, skills sharing, and rides. On the other hand, it was found that in Peru there are no formal activities related to car usage, shared trips, toy rental, book rental, used electronic, books, clothes, toys, clothes, DVD and games sales, service exchange, community support, or meal sharing; which requires business studies to determine whether or not there is a demand for such services that are not offered, so that they can be implemented in the future.
\end{abstract}

Keywords: Collaborative Economy; Peru.

\section{INTRODUCTION}

The term collaborative economy has changed over the years. If we were to ask an economic scholar 500 years ago in Peru, he or she would probably refer to the period of the Incas where communities or 'ayllus' practiced 'ayni', a form of exchange of work and collaborative effort that sought to engage one group of people (in families) to help another in different tasks (agriculture, construction, etc.) [7, 19]. Although film screenings began to spread between 1890 and 1895, it was not until 1899 that the first cinema in the world was opened in La Ciotat, near Marseille, with screenings by the pioneers of this art, the Lumière brothers $[6,12]$. Although the organizers did not know this, it became a pioneering example of collaborative economics.

The collaborative economy is a global movement and as such, it is also a movement that is present in Lima and throughout Peru [10]. Many people do not know it as such, but when you tell them about the initiatives and concepts, they immediately connect with the issue and appreciate the advantages and benefits of a collaborative vision [14].

In 1964, the sociologist Peter Michael Blau, born in Austria, set out his position on "the theory of social exchange" [3], making him the pioneer in touching on the subject of collaborative economics in the academic field. The author based his theoretical framework on two assumptions: the consolidation of any type of interpersonal relationship has its origin in self-interest, and the concept of individualism is innate in human beings. According to his theory, the social exchange should be seen as an exchange of favors, which supposes a previously established relationship, suggesting future researchers to study the conditions for such a relationship of exchange of favors, whose frequency is increasing and where trust is a key piece to enter the chain of favors [12]. 
We could conceptualize the collaborative economy as an economic system in which goods and services are shared and exchanged through digital platforms. The great success of this formula is that it manages to connect two groups of people very efficiently: those who have a need (for example, they need to be transported from one place to another) and those who have the idle capacity to attend to it at that precise moment (for example, someone who has a car and free time to take up a career). Today this can be achieved thanks to digital technologies, which allow interaction in real-time, even between users who do not know each other. The collaborative economy is already a matter of every day and we live with it, even if we don't realize it.

The term was first coined by Ray Algar in the article entitled "Collaborative Consumption", published in the April 2007 Leisure Report [1]. This term began to become popular in 2010 with the publication of the book "What's Mine Is Yours: The Rise of Collaborative Consumption", written by Rachel Botsman [5]. In Europe, the phenomenon of collaborative consumption began to emerge between 2012 and 2013, especially in the tourism sector $[13,17]$, although it has continued to spread in many other sectors, revolutionizing passenger transport and very recently the real estate market [15].

Some authors [18] have managed to identify all the current forms of the collaborative economy, organizing them into four basic groups of activities.

The first basic activity collaborative economy is collaborative consumption $[4,18]$, which aims to generate access to goods and services through the following legal-economic instruments such as bartering, renting, lending, trading, leasing, exchanging, reselling and swapping. The term collaborative consumption includes both redistribution markets, where goods are resold or redistributed from where they are not needed to where they are desired, product and service systems, where people pay for access to goods and not for their acquisition, and collaborative life systems, where intangible assets such as time, skills, time and space are shared and exchanged.

The second basic activity is called collaborative production $[4,18]$, in which groups, networks, or individuals collaborate in the design, production, or distribution of goods. The term collaborative production includes collaborative design, in which groups, networks or individuals work together to design a product or service, emerging from an open call to the public, a design report or a challenge, the collaborative development of products or projects, and collaborative distribution, in which the distribution of goods is organized and carried out directly between individuals.

The third basic activity is collaborative learning $[4,18]$, that is, learning experiences open to any subject in which resources and knowledge are shared to learn together. It includes access to courses, readings, and educational content, but also the offer to teach or share skills, or the public contribution of knowledge or problem-solving.

Finally, the fourth basic activity has to do with collaborative finance $[4,18]$, or financing, loan, or investment services that are provided outside traditional financial institutions. This is the case of crowdfunding or direct and mass financing of a specific project, or peer-to-peer lending, which connects those who wish to invest with those who need a loan, complementary currencies or alternative currencies to those legally used, which certain groups recognize as valuable for certain purposes, and collective insurance policies.

Nowadays, up to twenty-four categories for the collaborative economy can be found on the internet, which web site pages are related to car usage, car rental, bicycle usage, shared trips, toy rentals, book rentals, fashion items rentals, film usage, varied objects rentals, online commerce, exchanges, used electronics, used books, used toys, used clothes, used DVD's CD's and games, room rental, crowdfunding, skills sharing, knowledge sharing, community support, rides, and meal sharing [4].

According to Passoni [16], the public's reaction to the collaborative economy is very diverse: one sector of the population takes it as a new alternative to capitalism that substitutes market transactions for the action of sharing, another sector perceives it as the highest form of capitalism, at the same time, another small group of people is concerned about perceiving it as a possible scam on them, finally, a small group of people condemn it, feeling that it is a way of replacing stable jobs with occasional low-cost jobs

According to Time magazine, collaborative consumption is one of the ten great ideas that will 
change the world [2]. Likewise, García [11] states that New York Times columnist Thomas Friedman considers that the collaborative economy "creates new forms of entrepreneurship and also a new concept of property" and that MIT has calculated the potential of collaborative consumption at 110 billion dollars, when today it is around 26 billion, generating profits of around 3.5 billion according to Forbes magazine.

The internet has not only changed the way we see the world, but also the way we live it; the collaborative economy is proof of it.

\section{METHODS}

The qualitative approach was used, the design of this research was based on that of grounded theory, which was adapted to the study of social reality. This design has its background in Mead's Symbolic Interactionism and its ultimate aim is to understand how the world works. This design does not seek to produce formal theories, but rather to theorize about very concrete problems that may acquire a higher status as new studies from other substantial areas are added. In other words, the researcher will not seek to prove his ideas by generating grounded theory, but only to demonstrate that they are plausible.

The twenty-four categories related to collaborative economies on the Internet, proposed by Botsman and Roger [4] were reviewed and analyzed in the Peruvian context, to know whether or not there are companies (local or foreign) performing such activities at present, in case they do not exist, they were considered as market niches that will surely be covered in the future.

The review was carried out through internet searches, reviews in various advertisements, and literary reviews.

\section{RESULTS AND DISCUSSION}

Collaborative economy in Peru today. The "car rental" model is very common in Peru. Generally used by foreigners who stay in the main cities and need to rent a vehicle for about a week, the services can generally be hired within airports or through web portals.

"Bicycle usage" is very common in Peru, especially in residential areas. When the researchers did the online review of companies offering this ser- vice, they found at least forty companies offering this service, which denotes that it is a market with several providers, and probably several demanders as well.

As for the "film usage" business, it is common in Peru. There are many cases of local and international companies that offer access to watch their content (films, series, cartoons), for a reasonable cost. Even though the market is led by one company (Netflix), it is still a fairly attractive niche for new companies to start operations in Peru so that users have an increasingly competitive offer.

"Varied objects rentals" as a business model exists in Peru, it began as informal initiatives, generally advertised on social networks, but managed to condense into a business. Currently, there is only one company, of the Peruvian capital, that offers this service, in which practically anything can be rented.

"Online commerce" is very common in Peru, there are several companies dedicated to this service that have not only web portals but also mobile applications to facilitate this activity. This line of business has reached such maturity that it even has the international PayPal and local banks as strategic allies to facilitate purchase and sale transactions.

"Exchanges" through a virtual platform is an alternative that exists in Peru, however not through a company strictly related to the exchange, but to "online commerce" in which a client could offer an exchange instead of money. It is not very common.

"Room rental" is understood as the activity in which families give shelter to a traveler, inside their home, by renting him a room and the use of their electrical appliances. In this sense, this service already exists in Peru, led by a foreign company with a global presence, however, there is room in the market for the entry of other companies, so that it generates competition that benefits the public user.

"Crowdfunding" exists in Peru, it allows individuals to support other people's business initiatives and become financial partners. In Peru, this activity is supported by universities and non-profit organizations, which aim to generate business ventures that increase the quality of life in the community. 
The activity "skills sharing" is recent in Peru, after conducting in-depth research in advertising media, it was found that formally there is only one platform oriented to this activity, called Crehana, which through online courses that include, design, animation, web design, programming, photography, and digital marketing, among others, it seeks that people can learn skills related to marketing and advertising, it should be noted that this page has reported a boom in the number of visitors during the health emergency caused by the Covid-19 virus.

When it comes to talking about collaborative "rides" platforms, the Peruvian market is already exploited, both by global companies such as Uber, Easy, Beat as well as local initiatives.

Future of the collaborative economy in Peru. As for the "car usage", no companies established in Peru were found that offer such service, when searching all the results were directed to companies with operations in other countries (Brazil, Spain, USA). It was concluded that the rent of vehicles by hours is a good market niche, in case some company wants to undertake in this sector using the collaborative economy.

The "shared trips" are considered illegal in Peru. Despite being a highly demanded activity, the government stipulates it as a prohibited activity due to the insecurity caused by sharing a vehicle with strangers, which could lead to crimes. This activity is not carried out formally in Peru unless the law is modified.

No evidence was found of companies dedicated to "toy rental", however it is convenient to indicate that requests were found informally on social networks, from individuals requiring arcade games (billiards, arcade cabinet, inflatable games, etc.) for special activity days. Therefore, there is a market niche not formally served.

No formal activities related to "book rental" were found, after an exhaustive search, we could only find events (lasting one day) in which book lovers exchange or rent their books or comics, nothing more, without any company that supports the initiative.

The "fashion items rentals" is a booming business worldwide, there are several firms that are in the business of renting watches, bracelets, rings of great value, to be used in special meetings. The search did not find formal companies that provide this service at the level of luxury, only the rental of special clothing such as tuxedos, dresses, and kimonos for ceremonies such as weddings, baptisms, and first communion. This seems to be a business that could work in Peru since similar activities are successful in neighboring countries.

As for "used electronics", "used books", "used toys", "used clothes", "used DVDs, CDs, and games", those activities have been taking place regularly, however, not in platforms strictly created for each specific activity, but in a general platform, dedicated to "online commerce", in which customers must emphasize that used items are put on sale. In the future, it will be extremely gratifying to see the establishment of companies dedicated to these specific items, oriented to a single category of used product sales, as is happening in other countries in the South American region.

As for companies related to the "service exchange", the investigation found no such operations in Peru. Companies such as Bartercard or TaskRabbit (the leaders in this line of business worldwide) have not started operations in Peru yet, which is an exploitable market niche.

No companies were found in activity dedicated to "community Support", which seeks to connect users with other users who handle technical skills they can offer, such as painting, masonry, plumbing, locksmithing, etc. This is an unexplored market niche in Peru, which will surely attract the attention of several companies in the future.

"Meal sharing" is not yet developed in Peru, no formal companies were found that connect users interested in these services, so it is warned as a niche not yet explored, ready for study and implementation.

\section{CONCLUSION}

There is no doubt that the collaborative economy is a phenomenon that is growing by leaps and bounds and allows anyone to optimize their free time while generating resources, increasing their productivity.

This sample of innovation facilitates the exchange between individuals who, supported by technology that is easy to understand and apply, achieve their life goals. 
Naturally, this economic model has several challenges and difficulties that must be overcome to ensure its proper development. Meanwhile, the world continues to turn and seems to have chosen to collaborate.

\section{REFERENCES}

1. Algar, R. (2007, April ). Collaborative consumption. Retrieved from https://www.oxygenconsulting.co.uk/collaborative-consumption

2. Barrios, E. (2012). El "Consumo Colaborativo": una de las 10 ideas que cambiarán el mundo, según TIME. Retrieved from http://gestioninteligente.blogspot.com/2012/01/el-consumocolaborativo-una-de-las-10.html

3. Blau, P. M. (2017): Exchange and power in social life (2nd ed.). London: Taylor and Francis.

4. Botsman, R., \& Rogers, R. (2011): What's mine is yours: How collaborative consumption is changing the way we live. New York, United States of America: Harper Collins.

5. Botsman, R., \& Rogers, R. (2014). What's mine is yours: The rise of collaborative consumption. N. d.: HarperCollins e-Books.

6. Cárdenas Maldonado, J. D. (2019). Film Technique: A Modern Economy of Time, Body, and Soul. Palabra Clave, 22(2), 1-31. doi: 10.5294/pacla.2019.22.2.2

7. De Munter, K. (2010). Tejiendo Reciprocidades: John Murra Y El Contextualizar Entre Los Aymara Contemporáneos. Chungará (Arica), 42(1). doi: 10.4067/s0717-73562010000100033

8. Domínguez, J. F. M. (1978). La teoría del intercambio social desde la perspectiva de Blau. Reis, 4, 129. doi: $10.2307 / 40182727$

9. Foggenkamp, I. (2015, September 14). What's mine is yours, but for a price (Master's thesis).

Retrieved from

https://studenttheses.cbs.dk/bitstream/handle/10417/5672/isabelle_roggenkamp.pdf?sequen $\mathrm{ce}=1$

10. García Flores, C. J. (n. d.). La influencia del consumo colaborativo en el estilo de vida de la sociedad limeña en el Perú. Uso de los aplicativos móviles de Geolocalización en el Sector Transporte durante el período 2013 al 2017. doi: 10.19083/tesis/625408

11. García, M. (2014, June 21). La imparable economía colaborativa. Retrieved from https://elpais.com/economia/2014/06/20/actualidad/1403265872_316865.html

12. Gonçalves, M. A. (2012). Sensorial thought: cinema, perspective and Anthropology. Vibrant: Virtual Brazilian Anthropology, 9(2), 160-183. doi: 10.1590/s1809-43412012000200006

13. Guerrero, A. (2015, March 17). 3 casos de consume colaborativo para viajes. Retrieved from https://socialanimals.buzzmn.com/2013/03/3-casos-de-consumo-colaborativo-para-viajes

14. Jakovcevic, A., Franco, P., Visona Dalla Pozza, M., \& Ledesma, R. (2016). Percepción de los beneficios individuales del uso de la bicicleta compartida como modo de transporte. Suma Psicológica, 23(1), 33-41. doi: 10.1016/j.sumpsi.2015.11.001

15. Lopez, C. (2015, September 16). Nace una nueva forma de comprar y vender casas. Retrieved from http://www.europapress.es/comunicados/sociedad-00909/noticia-comunicado-nace-nuevaforma-comprar-vender-casas-20150916131918.html

16. Passoni, A. (2016). Economia delle piattaforme e architettura digitale delle scelte. Appunti sull'alternativa cooperativa. Retrieved from https://archiviomarini.sp.unipi.it/692/6/Economia\%20delle\%20piattaforme\%20e\%20architet tura\%20digitale\%20delle\%20scelte.pdf 
17. Rodríguez-Antón, J., Alonso-Almeida, M., Rubio-Andrada, L., \& Celemin-Pedroche, M. (2016). La economía colaborativa. Una aproximación al turismo colaborativo en España. CIRIEC-España, Revista de Economía Pública, Social y Cooperativa, 88(12), 259-283.

18. Stokes, K., Clarence, E., Anderson, L., \& Rinne, A. (2014, September). Making sense of the UK collaborative economy. Retrieved from http://collaboriamo.org/media/2014/10/making_sense_of_the_uk_collaborative_economy_14.p df

19. Zenteno Brun, H. (2009). An approach to the cosmic vision of the andean world. Punto Cero, 14(18), 83-89. 